\title{
Preaching to the choir: Patterns of non/diversity in youth citizenship movements
}

\author{
Sam Mejias and Shakuntala Banaji
}

\section{Introduction}

Studies over the years have argued for and demonstrated both the ethical imperatives for gendered, racial and ethnic diversity within youth educational and civic spaces as well as the instrumental benefits of increased diversity for the civic engagement and learning of all participants (Gurin, Dey, Gurin, \& Hurtado, 2003). In light of the largely white, generally middle-class and hierarchically male constitution of many youth civic organisations in the UK, other research has shown how young people from ethnic minorities could be said to belong to a range of 'civic subcultures' possessing distinct modes of and dispositions towards engagement (SanchezJankowski, 2002). Bringing these subcultures into the mainstream of youth civic and political participation has not been straightforward, even with the advent of the internet and smartphones (Banaji \& Buckingham, 2013). Paying attention to this difficulty and this goal, a common rhetoric, in many youth-focused or youth-led civic and political action groups in the UK, centres on the importance of promoting equality and diversity in politics in order to empower the participation of marginalised young people and their communities. Reaching such groups is an explicit and oftstated aim. ${ }^{1}$ In this context, inclusivity and diversity are framed as transparent concepts, and as an unquestioned good in practical terms. Yet there is often little thought given to how these rhetorical aspirations are either put into practice or are generative of outcomes in line with the broader goals of initiatives that characterise themselves as being concerned with diversity while also being accountable in ways that meet the frameworks of neoliberal socio-political reform. In searching for insight into how equality, diversity and inclusivity policies and practices are enacted within youth civic and political groups and organisations, this chapter draws on a year-long ethnography to explore the dynamics of diversity in two prominent youth-led political participation campaigns preceding, during, and after the 2017 UK general election. We specifically examine the rhetorical commitments to diversity expressed by organisational and campaign group actors in interviews and in public-facing communication strategies (events, digital media, texts) to make sense of how such rhetorics reflect or contest neoliberal notions of diversity, and in turn shape practices of inclusivity and diversity.

\section{Conceptualising diversity in a marketised world}

In the contemporary social moment, the buzzword 'diversity,' as a way of thinking about how the UK and other Western countries should structure social life, would 
appear to be fairly uniformly accepted by organisation leaders - in the UK at least one would struggle to find a youth leader, a CEO, a politician or a celebrity other than those with affiliations to the far right who would come out explicitly against diversity as a stated goal. But the word itself and the normative meanings it inscribes can be vague in both conceptualisation and application despite the wide acceptance and use of the term. Indeed, 'diversity,' performs a number of quite specific discursive and material functions that principally derive from a long history of struggles for equality and social justice across many institutional and political venues in the UK and elsewhere (particularly the United States and Canada). In this chapter, we consider the concept of diversity as comprising rhetorical articulations, institutional/structural policies, and symbolic and material practices aimed at encouraging less homogeneity in the demographic makeup of political, social and cultural institutions, and ultimately meant to redress historical legacies of global structural inequality. In the context of race, this homogeneity reflects a global history of geopolitical colonialism and imperialism by European and North American nations largely controlled by white (Caucasian) heterosexual males. Since W.E.B. Du Bois (2007 [1903]) first articulation of the metaphor of 'the veil' as a barrier between African Americans' realities and the vast privileges and power afforded to white Americans, the various forms of symbolic and material domination by Europeans (and Euro-descendants) of non-white 'others' throughout history from colonialism to contemporary society has been cogently theorised by scholars from both the Global North and Global South (Bonilla-Silva, 1997; Fanon, 1963; Hall, 1997; Said, 1995; Spivak, 1988).

'Diversity' discourse is therefore predicated on European colonialism and subsequent geopolitical domination and political racism. These phenomena set up the conditions for a unidirectional social construction of difference, where 'groups holding political and economic power construct racial categories to privilege members of their groups and marginalize outside groups' (Banks, 2005, p. 98). Historically entrenched patters of homogeneity emerge in virtually every sphere of public and institutional life and all privilege whiteness (da Silva, 2007; Delgado \& Stefancic, 1997; Feagin, 2013; Leonardo, 2002) and its intersection with maleness, heterosexuality and social class. It has been argued that the endurance of white domination and privilege in societies constitute and reproduce 'white racial frames' that 'assertively accents a positive view of white superiority, virtue, moral goodness, and action...[but features] a strong negative orientation to racial "others" who are exploited and oppressed'(Feagin, 2013, p. 10). For da Silva (2007), this racial frame is global because race is a necessary condition of and for modern globalised societies with the histories discussed. Indeed, while race is just one category for the construction of difference as it relates to current understandings of the purposes of 'diversity' for organisations, groups and movements - gender, disability, sexuality, class and age are vital and explicitly named aspects of most diversity agendas - it is the notion of difference in appearance, mainly via skin colour, that is typically understood in British organisations as constituting diversity (Ahmed, 2009). Therefore, although some organisations have gone down the path of assuming that the appointment of white women makes an 
organisation, body or committee 'diverse', the aforementioned race-based conceptualisation of diversity is the primary focus of this study.

\section{"Diversity" as neoliberal}

In recent decades, the UK and other nations have begun to address various forms of institutional homogeneity. Approaches to public policy, organisational management, and civic engagement have evolved in order to redress perceived representational imbalances (Stewart \& Lindburg, 1997; Wise \& Tschirhart, 2000) What began from social movements against racism and in favour of affirmative action as primarily a moral and ethical imperative to respond to the lack of representation and opportunities available to certain groups (and/or equally as likely, a legal requirement placed by governments on institutions in response to events or political struggles) has gradually become a marketised set of practices (Bowl, 2018; Kelly \& Dobbin, 1998) with outcomes that can be detrimental to the mission of anti-racism and the core goals of promoting equality and social justice as a response to systemic and institutional biases (Ahmed, 2012).

As the idea of 'managing' diversity as a field replete with missions, resources and administrative logics has evolved, so too have understandings and practices regarding how to combine moral, strategic, and increasingly, neoliberal imperatives in order to produce outcomes ostensibly aimed at 'increasing' or 'improving' diverse representation in organisations. Ahmed (2009) sees these competing discourses as being mainly about economic and moral value, pitting the 'business case' against the 'social justice case' for diversity, and contends that such a discursive logic 'reifies difference as something that already exists "in" the bodies of others' (p. 43), which enables a quantification and commodification of difference. Others have theorised UK government diversity policies as fully marketised 'products'. For example, through an examination of how British government film policies on diversity exclude the input of certain socio-economic groups in their representation, Nwonka (2015) suggests that diversity policy became the primary multicultural product 'sold' by 1990 s New Labour in order to advance political goals of multiculturalism and social cohesion. Other scholars point out that the language of UK government policy over the past four decades has effectively neoliberalised frameworks of 'participation,' 'empowerment,' and 'responsibility' entwining them with notions of and policies for 'community cohesion' (MacLeavy, 2008). This shifts responsibility for addressing problems of social unrest about inequality onto local communities comprised mainly of ethnic minorities - who are themselves ostensibly meant to be assisted by such policies (Ibid).

One particularly salient indicator of neoliberal subjectivity is the notion of brand management or enhancement, a cultural process that focuses on the performance of visibility to signify substance, and the performance of substance ('values') to generate 
profit (Banet-Weiser, 2012). Ahmed (2009) argues that the results of diversity - new, 'diverse' faces in the institution that offer 'evidence of commitment, of change, of progress' (p. 41) - offer a narrative of success that organisations use to point to how they have 'solved' the problem, enabling them to end the conversation before undertaking any meaningful examination of the (economic, social and political) layers of discrimination. Little happens beyond having 'different looking people' at the office or in the room. An aura of diversity, through its implications of positive, progressive and morally commendable change, can also make institutions, localities and groups more 'marketable' or 'cool', while simultaneously masking racism, classism and other inequalities through a focus on 'looking and feeling good' and an obscuring of 'the rotten core behind a shiny surface' (Ahmed, 2009, p. 44). In this view, diversity work is fundamentally about managing perceptions instead of being about working for justice-oriented systemic change. Such a view lends further support to arguments that neoliberalism compromises human rights struggles, as we are 'condemned to watch but powerless to deter' (Moyn, 2014, p. 151) its effects on societies.

\section{"Diversity" as disempowering, obscuring, and redirecting struggles for structural justice}

As the terminology of 'diversity' has taken on neoliberal characteristics across Western institutions via its insertion into neoliberal practices and discourses, the use of this phrase has also been enacted in ways that can stifle difficult questions about the long-term impact and implications of a diversity agenda which has cut itself loose from critical feminism, anti-racism and equity. Scholars have argued that the application of neoliberal imperatives to 'construct docile ways of talking about diversity is a way of preserving the cultural order' (Matus \& Infante, 2011, p. 305). Sara Ahmed (2007) argues persuasively that the discourse of diversity in professional institutions can become decoupled from the original purposes of social justice and equality that have driven movements for enhancing inclusivity and diversity in the workplace and other social and political institutions. In other words, neoliberal values imbue discourse about diversity with new dimensions of understanding that devalue the aims of diversity actions. The malleability of the concept of diversity - shorn of the contexts of struggle in which it emerged - can be most problematic. What counts as diversity is then shaped by those in positions of power, more likely than not individuals with economic and social capital, largely white, and this openness to cooption may in fact allow for the defining diversity in 'ways that reproduce rather than challenge social privilege' (Ahmed, 2007, p. 240).

Examining public service broadcasting in the UK, Malik (2013) argues that an 'incremental depoliticisation of race' has changed the nature of diversity initiatives and policies from a focus on multiculturalism, to one on cultural diversity, and finally to one on creative diversity, a phrase and conceptualisation characterised by 
classlessness and 'racelessness' due to its 'lack of engagement with inequalities and racisms' (Malik, 2013, p. 239). Ahmed (2009) cautions that the manner in which organisations construct diversity discursively as an end in itself - as if the presence and actions of diversity initiatives and policies represents a transparent, ahistorical and adequate solution - can undermine efforts to confront racism:

For Black staff in the diversity world, the recognition of the ongoing nature of racism is constantly blocked. Organisations wanted to talk about diversity rather than racism. Diversity becomes a technology for not hearing. (Ahmed, 2009, p. 47)

Diversity, while regarded as both an aspirational and moral end that satisfies neoliberal managerial imperatives as well as responds to government-mandated initiatives, nonetheless can obscure the broader purposes of such schemes to recognise and combat institutional racism and other forms of structural violence against historically marginalised groups. In doing so, diversity as discourse supplants and obscures more transformative or revolutionary discourses of structural change and systemic justice. When unreflexively applied in any organisational context from the most well known global corporations to social movements and educational institutions, the notion of diversity can be a lever for opening up conversations about discrimination, but can also come to act as a discourse to create 'comforting' spaces where questions of equality and equity are actually pushed aside (Matus \& Infante, 2011). Ahmed's call to 'refuse the injunction to be happy objects for the organisation, which means being willing to cause trouble' (Ahmed, 2009, p. 41) suggests a radical course of action for diversity practitioners in organisations and other institutions and equally an uncomfortable one for those radical anti-racist and feminist young people operating inside the already hard-pressed youth civic sphere. Under this view, in order to achieve any progress in promoting social justice and equality, diversity-in-practice must involve a critical restructuring, and must unsettle existing demographic paradigms beyond recruiting for difference. With this vision in mind it is useful to recognise the reality of structural inertia in the contexts in which diversity initiatives are situated:

Most [diversity] practitioners are appointed by organisations to transform them. But being appointed by an institution to transform it does not mean that the institution is willing to be transformed. (Ahmed, 2018)

\section{The promise and problems of youth diversity in UK active citizenship}

Although there are reasons to question whether there is or ever was just one version of what constitutes public good (Banaji, 2008), civic engagement ostensibly offers opportunities for young people to work collectively for the public good (Checkoway, 2009). It is therefore an area of particular importance when looking to understand how struggles for equality and social justice are negotiated through collective civic 
initiatives, movements and organisations. Set against the backdrop of on-going struggles to make British institutions more diverse, the youth voluntary and civic sector in the UK, like many other sectors of public life, has started to represent itself as being inclusive in its encouragement of participation and engagement. From websites that foreground young people wearing rainbow symbols and dreadlocks to policy documents on inclusion and diversity, evidence of this rhetorical change exists. Yet experiences of discrimination based on age, gender, race, ethnicity and other protected characteristics are still rife, and structural barriers to achieving meaningful equality of participation and opportunity also persist. Young middle- and higherincome citizens are disproportionately likely to have more political influence (Levinson, 2010), while the promise of the Internet to democratise and expand participation for young people remains contingent on social differences in race, class, and age (Banaji \& Buckingham, 2013). Our previous research has also demonstrated the ways in which public policy and news discourses in the UK consistently devalue and marginalise active youth citizenship (Mejias \& Banaji, 2018). Hampton's (2010) research shows that even in settings where the ostensible aim is to create equality of opportunity for young people from different backgrounds, existing inequalities are reproduced by covert, structural and unconscious racist biases within civic organisations. Alongside economic and discursive power, this chapter follows Hampton (2010) in recognising the importance of social capital in challenging or reproducing social inequality, and in applying these concepts to the study of race and diversity.

In an ethnographic study of a voluntary youth association that focused on race and the development of social capital, Hampton and Duncan (2011) found that white youth were more likely than their black peers to exhibit racial homophily, and that institutional actors played a significant role in solidifying or bridging racial barriers. Their study found that trust was a critical factor in influencing the formation and collaborative potential of network members, which in turn helped to develop social capital. They argue that:

Emphasising racial identity and the institutional context of a voluntary association highlights the importance of trust. Social relationships are shaped by power, social inequality, and the informal dynamics of trust, and social capital is linked to the opportunity structures that tie people to resources through a network of embedded social relationships. (Hampton \& Duncan, 2011, p. 478)

Their study also illustrates how young white people were more likely to affiliate with other whites, while black and brown young people were more likely to form links both within and across races, a pattern of racial homophily where 'whites were less likely to pursue bridging relationships with peers that transcended race, gender, and educational boundaries' (Hampton \& Duncan, 2011, p. 487). This finding about white homophily poses challenges for broadening diversity in majority white networks and settings. 
Another significant challenge is to recognise the contested nature of citizenship and civic experiences specifically for young people, who are often not yet considered 'full' citizens, which shapes different understandings of citizenship that can either be inclusive or exclusive of young people (Smith, Lister, Middleton, \& Cox, 2005). In this sense the notion of diversity as applied to a youth active citizenship context takes on an additional meaning reflecting conscious work towards mitigating age and racial inequalities.

Enabling more meaningful engagement for young people with the subject of diversity requires consistent opportunities and attention. For example, in a study of youth dialogues in Detroit, Checkoway (2009) showed that when exposed to specific opportunities for civic engagement around racial and ethnic identity, young people from diverse backgrounds were actively engaged. When youth civic and political organisations offer explicit opportunities in good faith to consider and act upon questions of diversity and community cohesion, young people come forward to take up these opportunities.

Recognising both the contingent nature of diversity work, and the ways in which existing social inequalities challenge the potential for youth civic participation practices that advance equality, the remainder of this chapter explores how two youth political movements articulate and perform diversity as a part of their work. The aim of this chapter is to better understand how diversity in such contexts either reaffirms or transcends problematic discursive constructions - where the enactment of diversity becomes the solution to the problem - in favour of the more difficult pursuit of disrupting institutional life to confront structural injustice. In the cases that follow, we examine how two grassroots movements with similar political goals but widely differing approaches construct diversity discourse and work.

\section{My Life My Say and Momentum: A portrait of youth-led politics in the Brexit era}

In an ironic turn considering the nature of our investigations into young people's active European citizenship, our ethnography was both fortuitously timed and deeply enriched as a result of the endorsement of the UK's exit from the European Union by 51 percent of the referendum voting populace in June 2016. The Brexit vote and its aftermath appeared to spark a surge in youth political interest in the country, as the following year saw a visible increase in youth group organising, campaigns, grassroots actions and mainstream political engagement (Sloam \& Henn, 2018). By notable majorities, young people expressed dissatisfaction and dismay at the direction of the country and the future that Brexit would bring (Mejias \& Banaji, 2017).

Our two selected cases were particularly well suited to exploring the role and place of diversity in their respective activities. Led by a charismatic young local politician from East London of Turkish descent, My Life My Say (MLMS) is a grassroots youth 
political participation charity aimed at providing meaningful opportunities for young people to learn about and engage in British politics. Their main activities involve organising café-style political discussion events for young people called Democracy Cafés, and standalone youth campaign public talks or panels, often featuring prominent national and European political figures and held in Parliament or European Union institutions in London (e.g. European Commission).

In contrast, the second case study, Momentum, is a grassroots campaign group that emerged from a particular demographic of left-wing, socialist grassroots activists traditionally aligned with the Labour party. When the group first began their work in late 2015, Momentum boasted a political hybridity unique in contemporary British politics, largely attributable to the uniqueness of their leader, Jeremy Corbyn, a (socalled 'radical,' far left) socialist voice leading a mainstream party. Although Momentum is not an organisation per se, they were highly organised in the service of supporting Corbyn and therefore the Labour party. As such their approach to diversity reflected in many respects the Labour party approach, which involved the creation of specific diversity initiatives and accompanying personnel, and recognising diversity as a plank in a wider political platform. It is particularly important to note the context here, as Momentum, unlike the Labour party, operated on miniscule budgets and often had more volunteers than paid staff working there at any given time.

We began working with MLMS and Momentum in early 2017, before Prime Minister Theresa May made the unexpected decision to call a snap general election, which sparked a tidal wave of campaign activity in both groups. Once the election had been called, we followed both groups for the duration of the 2017 general election campaign to understand what role 'diversity' played in generating support for their preferred general election candidate and party (for both, Corbyn and Labour).

\section{Methods}

During our year-long ethnography of MLMS and Momentum in 2017, our team was particularly interested in how diversity fit into the vision, policies and practices of both groups. In interviews with key informants, we asked direct questions about their views on diversity within their respective groups/organisations. We also used field notes to document when 'diversity talk' and 'diversity work' were absent or present during ethnographic observations, and what forms such talk and work took. In interviews and informal conversations, we were mindful of how context-contingent many of the answers to our questions might be. As researchers present during what became the busiest and most successful period of both MLMS and Momentum's existence, we knew that it could be difficult to probe the quality of engagement with anti-racism and commitments to a diverse membership during a campaign in which 
most people were overworked, unpaid, and focused on the wider goal of winning an election.

In addition to interviews and observations, we analysed each group's digital media communications on Twitter and Facebook. Analysis of public communication repertoires on social media (the most prominent public platform for both groups) offers an opportunity to examine the organisation's enactment of diversity across multiple levels: first through a surface-level analysis of the appearance of diversity (highlighting what type of people are most likely to appear); secondly, by illuminating the logics of visual representation (in what contexts is diversity visually represented?); and thirdly by investigating when and how diversity work (i.e. initiatives, projects, policies or programmes) is communicated publicly.

Our analysis involved triangulating interviews and observations with public-facing communications in order to more broadly elaborate how diversity work 'works' for each group during a time of considerable activity and heightened visibility due to the 2017 UK general election campaign. In the following sections, we explore how each group conceptualised and enacted diversity as part of their youth active citizenship projects, to better understand the place of a diversity agenda in these two youth-led civic engagement groups.

\section{Conceptualising and enacting diversity work}

This section draws on interviews, observations, and public-facing communications of both cases to explore how diversity was conceived within each and across both. During our work with MLMS it became immediately clear that one of the dominant frames guiding the organisation's rhetoric and actions was a commitment to the promotion of diverse age groups and that bringing more young people into the national political conversation was a recognised form of diversity work that relied on the same rhetorics of equality and inclusivity as the discussions around race. Similarly, workers and volunteers at Momentum often framed their cross-generational membership as a positive aspect of their movement. We therefore include in our analysis perceptions of youth as the face of diversity to consider how young people themselves are framed as actors who contribute to diversifying the civic and political arena.

\section{My Life My Say: Diversity as foundational, explicit, networked - and neoliberal}

MLMS is in many respects a one-man show, founded and run by a young and ambitious London politician with a compelling story of youth active citizenship, and influential networks within British and European institutional politics. As one of the youngest-ever elected local councillors in London at the age of 21, as well as a former talent scout for the Premier League football clubs Arsenal and Southampton, the 
$\mathrm{CEO}^{2}$ started MLMS as a charity that could mobilise youth participation in politics. MLMS was explicitly founded on the advancement of specific diversities (youth, racial, and political) within politics, and during our ethnography we identified a consistent organisational logic that permeated its communicative practices and also seemed to rely on the engagement of existing 'diverse' personal and professional networks.

MLMS positions itself as a youth-led charity aimed at bringing young people into politics by relating politics to their everyday experiences and concerns. MLMS refers to this focus on demystification (through direct encounters with political figures and events) as 'rebranding' politics, parlance evoking a neoliberal framing (Banet-Weiser, 2012). Using 'rebranding' this way conveys a dual message: that politics has an optics problem wherein it is to blame for not surfacing tensions and stakes in a way that resonates with young people; and that young people are unable to make meaningful and relevant links between their lives and political activity in the UK. Use of market language of 'rebranding' invokes both capitalist and creative frames to present political perspectives as potential commodities for young people to relate to and become loyal to or aligned with.

Aligning with Ahmed's (2007, 2009) observations, MLMS relied heavily on the marketing of diversity - youth, racial, political - as one of its unique selling points to generate support for their work, to promote positive associations, and to also demonstrate success. During observations and interviews, MLMS representatives framed young people and particularly young ethnic minority people as being outside of institutional political deliberative processes in the UK, and in need of better systemic representation in order to take forward concerns to policy and decision makers. MLMS' conceptualisation of diversity therefore assumes that young people suffer from a number of systemic participation deficits which have to be overcome. For MLMS, young people are not adequately represented by politicians: there are too few who are young and hail from similar backgrounds to the diverse UK youth population; they are not given the proper tools or opportunities to assess how politics is relevant to their lives; and they have little recourse to having their views considered and acted upon by politicians. This construction of its mission links young and racially diverse people via of the label of marginalised populations. MLMS' CEO often pointed out in public speeches a lack of young and/or minority politicians currently and historically in Parliament, citing it as a motivation for his entry into politics at a young age:

I've always been a strong advocate of institutions reflecting the people it represents. The average age of councillors is 65 in the UK. Why don't these chambers have people that represent the views of the young people?

\section{Interview with MLMS CEO, February 2017}

In terms of the types of young people it seeks to influence and involve in politics, we observed that MLMS conceptualised itself as a space especially for young people who 
come from backgrounds historically underrepresented in institutional politics. The organisation's focus on including young people from such backgrounds was easily observable at all of their events: young people from Black and Asian communities were often in the majority at such events. This explicit targeting of young people appeared to be closely linked to the CEO's own identity as a young Muslim of Turkish descent, and to his inner London social and professional networks of Black, Asian and Minority Ethnic (BAME) young people. Suggesting the significance of communities, and of having politicians from a range of racial and social backgrounds, many of these young people were personal friends recruited to either be trustees, occasional representatives, or attendees at his youth events. On several occasions in public speeches or presentations, in private conversations and in official research interviews, the CEO explicitly stated that MLMS exists to support youth voices not normally seen in formal politics - black and brown young people, young people from poor and marginalised communities, young people without expensive private education, and young people living in cities. During MLMS' efforts to engage young people in research on their views about Brexit, he also prioritised the engagement of young 'Leave' supporters and young people from poor rural areas, whom he identified as primarily white, working class young people.

Consistently throughout our research MLMS appeared to strive to implement activities that foregrounded the importance of the diversity of its participants. Indeed, the racial and ethnic diversity on display at MLMS events may partially explain the sustained nature of support given to the organisation by the European Commission, UK Parliament, and other political institutions. MLMS events usually felt different to many of the other youth citizenship programmes and events we attended as participant observers during the time of the ethnography. There was a level of visible racial diversity not usually seen in Parliament or in European Union buildings. Our field notes document 'a satisfying, utopian feel' to many of the public events. The combination of youth engagement and racial diversity performs a specific type of positive visibility for all involved. MLMS displays diversity, funds diversity, but encourages a very surface level engagement with politics. As Ahmed points out, everyone feels good.

At these public events, in addition to the audiences, the panels selected by MLMS was notably diverse. There was a constant focus on diversity of appearance and perspective, as the CEO often took great effort to ensure that speakers actually looked like and reflected the experiences of the audiences for their events. At standalone events such as MLMS' launch of its Brexit-related participation project at Hackney House in London on 12 April 2017, participants were invited into diverse worlds of Black British YouTube influencers, artists, poets and researchers, each of whom gave short talks (a white, conservative Brexiteer was also invited to speak at this event, and although the crowd was noticeably opposed to his comments, they were respectful and engaged). On the other hand, their series of Brexit cafés funded by the European Parliament Liaison Office in the UK from July to December 2017 featured an invited 
MEP at each event (4 white women, 3 white men) who spoke to the lack of diversity within British political institutions.

Perhaps unsurprisingly, in observations of their public events for young people and in photographs of sessions we did not attend, it was evident that the geographical location played an important role in selecting the kinds of young people who participated. By the organisation's own estimation (discussed in conversations with our researchers), sessions held outside of London tended to include a larger proportion of white young people than those held in London, although social class was less easy to estimate. As we did not observe any MLMS events taking place outside of London, nor were we privy to its youth recruitment strategies more widely, it is difficult to assess the ways in which MLMS attended to other aspects of diversity and inclusivity - for instance around sexuality, religion, and disability when recruiting participants in their events for youth.

Certain public events demonstrated a dual focus on engaging young diverse youth while simultaneously marketing MLMS to a national audience. One such example was the Democracy Café event held in central London in May 2017, in which two nationally prominent female Black British public figures - the barrister and antiBrexit activist Gina Miller (GM), and the barrister and Guardian journalist Afua Hirsch (AH) - were invited speakers, along with several local politicians from each of the main parties (Labour, Tory, and Liberal Democrats). As an observer it was difficult not to be overwhelmed by the sheer number of media outlets capturing the event:

The general impression is that this event is too media saturated. Every table discussion is being captured by either a video or an audio recording, some tables have multiple recording device people doing their thing on the outskirts of the table. Some of the participants are adjusting themselves every so often to the big cameras getting in people's faces. At the same time virtually every MLMS staff member is also capturing the event on their phones and iPads. It is interesting to see AH and GM as well as the Labour and Tory politicians actually sitting with young people and having a conversation, but as they're all flanked by media or devices of some sort, the flow of the discussion feels a little forced.

Field notes, May 2017

At least five news stations were present at the event, including BBC, London Live, and even a German radio station. The event appeared to show MLMS working towards two clear goals: to deliver a meaningful event for young people, and to generate visibility for the organisation and its work. There was considerable substance to the roundtable discussions between young people and the politicians, journalists and activists that were present. There were also well-rehearsed political speeches by the celebrities present, demonstrating the celebrity clout of the organisers. And the number of those documenting the event was so high relative to the number of youth 
participants, that the event from beginning to end resembled a fevered marketing exercise. This speaks to how focused MLMS was on attracting national visibility to their cause, by marketing their youth and diversity work as news story 'products' being sold for national and European audiences.

\section{INSERT FIGURE 5.1 (Banaji-Mejias Figure 5.1 IMG_8157)}

Analysis of our observations and interviews foregrounds that the young people who participate in MLMS events and follow its social media activities are intended to be recipients of a positive message of youth engagement. They are encouraged to see in the CEO an example of BAME youth citizenship success - in fact of empowerment that can be emulated; and in light of this role model, to re-conceptualise politics and its relation to their lives as young people. Encouraging this emulation, MLMS' CEO often brought young black and brown people from his social circles into the organisation as volunteers, staff, or emissaries. In one example, a long-time friend of the CEO was recruited to participate in a focus group session when the session was low on numbers, and also called in last minute to represent MLMS at an event of a fellow British youth organisation that the CEO could not attend. He was described to our researchers as a 'trustee' but it was also clear that the relationship was more friendly and informal which allowed for last minute favours. In conversation with one of our researchers, MLMS' CEO framed this as an opportunity for his friend to get more involved, in a way that celebrated the potential positive outcomes of pushing his friend into youth citizenship action. It also suggested that for the CEO, looping in youthful friends who could freely donate their time to help out their politician-youth activist friend was a well-tested strategy for extending the reach and visibility of his MLMS brand within the world of institutionalised youth politics. This engagement of a personal circle of friends and supporters may potentially limit the pursuit of diversity and inclusivity goals to those contained within self-selected networks.

\section{Diversity in organisational communications}

When it comes to public-facing communications, MLMS relied primarily on Twitter, Facebook and Instagram to publicise their projects and events. Their visual representations were very diverse, more often than not featuring pictures of black and brown young people. There are also interesting choices made in MLMS' public communication that indicate a close attention to the details of performing diversity. For example, while seemingly inconsequential in isolation, a close analysis of MLMS' Twitter feed from February 2017 to January 2018 showed a remarkably consistent usage of emojis with different skin tones. Most often this was manifested in a white 'fist bump' emoji next to a black 'fist bump' emoji, but there were also usages of a 'pointed finger' emoji in both black and white skin tones. This subtle but clear decision to duplicate an emoji with two different 'races' performs the work of 
signifying racial solidarity, which would appear consistent with both their event and participant profiles.

\section{INSERT FIGURE 5.2 HERE (Banaji-Mejias Figure 5.2.png)}

Although MLMS consistently updated their social media feeds with new posts, their social media strategy did not appear to be focused on expanding their social media network. They added roughly 900 followers between 28 March 2017 (when they had $5,218)$ and 12 January $2018(6,118)$. Yet at every event our researchers attended, the imperative to document goings-on for social media sharing was paramount. The CEO or an MLMS staff member would take pictures, and post either staff selfies, pictures of VIP attendees, or pictures of MLMS or other organisational branding present at the event, and instantly upload to social media (in particular, banner placement for the portable MLMS banners was always an important task during each event in order to achieve the best visibility for the brand). However, there was little evidence that MLMS actively sought to recruit or engage more young people via social media throughout 2017. What was in full evidence, however, was a frequent exhortation to participants in its public events - who were very often themselves either young people of colour, or linked into the work of MLMS via the CEO's personal and professional connections - to use social media to promote the particular MLMS event or initiative taking place. In this way, it was possible to observe in real time the formulation of participatory filter bubbles (Pariser, 2011) in the online world, specifically in relation to how MLMS encouraged the use of social media to 'tell your friends' about getting involved in politics. Crucially, the aim of such calls to connective action (Bennett \& Segerberg, 2012) was not explicitly about building new audiences and constituencies for the MLMS movement; rather, it was about bringing in the networks of existing participants into the MLMS movement.

In addition to social media MLMS were particularly careful to document how often their organisation was mentioned or featured in mainstream and legacy media. MLMS shared with our researchers an internal document entitled '2017 MLMS Mentions' referring to instances when the organisation was featured or mention in a media or news item. The document itself, which aggregates a total of 54 mentions for the year, is telling in terms of the value placed by the organisation on media visibility (and on sharing the record of that visibility as a way to generate additional support). Reviewing these media mentions reveals an occasionally savvy use of the media to generate visibility for the organisation. For example, an Evening Standard article about getting young people to vote ${ }^{3}$ that featured actor/activist Emma Watson, cited MLMS's work, quoted one of its Asian female staff members encouraging all young people to vote regardless of political preference, and offered impact statistics about 
MLMS' work. In the context of the article it reads as a sort of glowing recommendation or advertisement.

Similarly, in internal communications regarding fundraising, MLMS recognised that their mission to advance diversity in institutional politics represented a valuable commodity for attracting potential supporters and funders. In a conversation about applying for funding, the CEO felt that in drafting a proposal 'our main highlight needs to be that the most marginalised through the organisations we are working with will have their voices heard through a structured engagement platform,', referring to the All Party Parliamentary Group (APPG) for a Better Brexit for Young People that MLMS had set up, and through which a number of its highest profile research and public engagement projects were being implemented. The CEO also added that their proposal should emphasise "the diversity of views in the APPG," which refers to the careful work of bringing in youth participants who were both pro- and anti-Brexit. This approach - to leverage their identity as a racially diverse, multi-cultural youth charity for support - is sensible and pragmatic for a grassroots youth organisation with no sustained funding, run by two paid employees and a handful of interns, volunteers, and part time staffers. The act of selling a diversity product in order to influence politics in the direction of institutional equality reveals again how neoliberal values appropriate and compromise justice struggles (Moyn, 2014).

\section{Other aspects of 'diversity'}

There seemed to be little consideration of gender in the conceptualisation of diversity at MLMS; nor was there any explicit acknowledgement, on the part of the organisation, about the importance of gender diversity and inclusivity. It is, therefore, difficult to draw conclusions regarding an organisational commitment to gender equality except by noting an absence of engagement with gender politics as part of their youth active citizenship work or as part of their understanding of the meaning of diversity. In its own organisational representation, all of MLMS' paid part time staff apart from the CEO were young women. Several young men acted as volunteers or interns during our study, but none were hired as paid staff. During our study at various stages we interacted with six young women who worked for MLMS either part or full time; three were White British, one was Black British and two were from Asian British backgrounds. At its public events, and with regard to speakers, there was usually a relatively even level of gender representation. However, the collected data strongly suggest that MLMS' definition of diversity was most often in reference only to racial and ethnic diversity of young people, or to young people as diversifying the age profile of active citizens. Furthermore, the gender hierarchy between the male CEO and his female staff members was often highly visible during our observations of private and public events. 


\subsection{Momentum: Diversity as implicit, contingent and rhetorical}

In contrast to MLMS, Momentum's focus on diversity was considerably less explicit or visible. We found that Momentum's identity was implicitly diverse in terms of age profile. We also observed how the national office and its subsequent public communications team embodied a youthful identity and practices contingent on young people occupying important leadership roles within the national structure. Overall, apart from the diversity of ages within the organisation and the number of young women involved at different levels, our study found that Momentum's conception of, commitment to, and practices around racial and class diversity and inclusion were largely rhetorical.

As a cross-generational grassroots campaign group which at times verged on being a social movement, Momentum's conceptualisation of young people was accessible through participant and non-participant observations but never explicitly stated. During our fieldwork, the idea of 'youth' as constitutive of Momentum's identity was apparent particularly through the ways in which young people under the age of 30 worked within, were represented by, and became interested in the work of the organisation and of the organised, party-linked socialist politics it represents; and in terms of how the organisation's campaigning and activism reflected and attracted young volunteers and paid staff. Staff at Momentum showed a keen understanding of how 'young people' as a category are perceived and stereotyped both within and outside of the organisation. In particular, there was a clear recognition of the major gap between the mainstream media portrayals of Momentum's 'youthfulness' - as a violent youth movement of extreme left militants ${ }^{4}$ - and the perception within the organisation of a dedicated, politically compassionate, and professional group of youth activists working for egalitarian social change through institutional political structures. There was also a sense within Momentum that it had become associated positively with at least a segment of a generation of young people eager for a change to the status quo of British austerity politics. Its social media team played an important role in projecting this youthful identity while also bringing in further youth supporters. Led by young people who had grown up using digital media, smart phones and apps, and also adult professionals in filmmaking, its sharp understanding of effective social media video dissemination and telephone messaging for virality played a critical role in generating support for the Labour party during the 2017 general election campaign.

One leading staffer who was 29 when he joined Momentum shared his view that the appeal of youthfulness was important but also unrepresentative of the membership overall:

We do try to give that appearance of being young, youthful and vibrant and stuff like that. But it's also just a media narrative. Majority of Momentum members aren't young. The majority of Momentum's active members, people who actually get out, campaign, do stuff, are older. 


\section{Munir, 31}

The response of this staffer and others recognised that the perception - or branding of youthfulness was an important part of the group's identity. This was usually acknowledged in a visible way in two particularly important areas - within the makeup of the national office's staff (where young people occupied central roles), and as part of their organisational activism strategy, which included minimal joining fees ostensibly aimed at attracting young people with lower incomes. Despite the appeal to youth, the local chapter structure of Momentum and its linkages with traditional Labour party meant that most active members were locals over the age of 30 .

Our ethnography revealed an important connection between the age profile of the national office staff and the subsequent emphasis on using social and online media and other youth oriented activist and media approaches to generate support for Jeremy Corbyn and Labour during the 2017 general election as an aspect of Momentum's national campaign strategy. In particular, practices of instant-response social media content creation for virality, and of framing issues in ways that resonated with young people, were used with what we consider to be success. One staff member shared:

[We] have ultra-young staff teams as you can see. Which then like played back into the movement through like the content put out... the way we frame things and the kind of tools that we design.

Jim, 25

Young people working at Momentum's national office very often occupied positions of significant authority across critical areas of work, including communications and public relations with mainstream national news organisations, leadership of creative and digital media campaigns, online-to-offline organising of canvassing and get-outthe-vote efforts, activist trainings, and event planning and management. Because the national office coordinated national strategy and action, Momentum's seemingly ceaseless creation of digital content - informational, satirical or motivational videos responding to breaking news about Labour or Theresa May, quickly turned around and sent either to members or posted to social media to generate hits or keep followers informed - combined with the presence of young people in the national office at high levels of responsibility almost always ensured that a young person would be the 'face' of Momentum in much of its public-facing media content. Excerpts from our field notes reveal a familiar occurrence:

Earlier this afternoon I was upstairs on the roof doing an interview with Munir. Brenda was also there being recorded by one of the camera guys rattling off another inspirational message to the Momentum supporters to be quickly turned around and sent out either on the social media channels or in a supporter email. I asked her, 'Is this all you do here, shoot promotional videos?' A little while later in the office I 
heard Ernie and Tino joking about Brenda being 'the young face of Momentum.'

Brenda was enjoying the debate and smiling.

\section{Field Notes, Momentum National Office, Nov 2017, Whitechapel}

In interviews with both younger and older adult staff at Momentum, some mentioned how the current generation of youth political grievances could be directly - and unfavourably - compared to the entitlements and affordances that were granted to older generations of British citizens during their youth. One of Momentum's adult founders succinctly summarised the dilemma of youth discontent with austerity Britain:

I didn't have [university] fees to pay. I got a grant. I could sign on and collect [a welfare payment], and if I didn't get a job in the holiday periods I could sign on and I didn't have to work at university. Whereas now people have to work all the way through university and may leave with debt the size of a bloody mortgage and they can't get any housing. [It's] generational inequality.

Jake, 60

A younger staffer echoed these thoughts on generational inequality, attributing the rise of Corbyn's popularity directly to his appeal in terms of young people's desires for a different kind of society and to young people's discontent with the current systemic inequality:

Corbyn-ism was in a large sense or in a certain sense a youth movement because young people are getting fucked and have been now for ages and obviously they wouldn't turn up to vote so obviously no one cared instead of like putting forward policies that actually affected them. But then that spawned and influenced organisations such as Momentum.

Jim, 25

By framing their political agenda in terms of differential experiences of government benefits between older and younger generations (and subsequent quality of life issues), Momentum adopted a logic of youth rights. When paired with the contingent affordances of having young people in key communications roles at the national level, this generated powerful political communication narratives for audiences that implicitly articulated Momentum as a youth-focused political movement.

By privileging the voice and rights of youth - albeit a specific subset who did not necessarily reflect the diverse range of British youth - as part of their campaign work, Momentum demonstrated a commitment to the promotion of structural change as it related to diversifying the participation of and social welfare for young citizens: 
addressing generational inequality, as Jake put it. However, while this did show a commitment to advancing equality through an agenda that recognised the diversity represented by youth, it was less vocal regarding racial or gender diversity.

Momentum occupied a much more rhetorical position in relation to practices of racial diversity. While our respondents frequently spoke of the importance of diversity, there was little evidence of its prioritisation. The young people working at Momentum during our fieldwork were mostly white, and many were university educated (some were involved in the UK Uncut movement beginning in 2010-2011 around antiausterity action). Many working-class young people with similar feelings of scepticism about government policy and hopes for a different government would not have had the financial means to survive while volunteering their time at Momentum. One of the older staffers we spoke with referred to some of the young people working at the national office as 'middle class.' She made the point that young people who can't afford not to work because their families and they themselves are dependent on those wages (even low ones) are unable to be involved in the same way as most of the Momentum volunteers. Her recognition of the connections between a certain level of economic privilege and political engagement were incisive and self-aware. Belonging to a particular social class does not denigrate the choices and commitment to an alternative politics which led the young momentum volunteers we worked with to donate time for which there were many competing demands; but it might explain the difficulty that the organisation faced in its model of wanting to attract and yet being unable to sustain the participation of a wide class spectrum of youth.

Another key staff member, one of just three national officers (out of approximately 25) who was not white, affirmed the central issue underpinning the lack of class, ethnic and racial diversity, and suggested that this applied even to paid staff:

Diversity [at Momentum] is terrible, it's really bad. In terms of our staff team and volunteer team, there's definitely an economic issue. In that we pay shit. So, you have to be a person in an economic situation that allows you to get paid crap money to do incredibly time-consuming work. So that a) takes out people with care duties, people with family duties. So, majority of people are young, single or in a relationship that hasn't reached into that point yet. And then on top of that, so much of the left is based on people you know, people who get involved - it's been dominated by white middle class people for so long. And that hasn't been addressed. So, whereas Momentum as an organisation has that problem, we're in the fortunate position [that this is] recognised.

\section{Munir, 31}

Munir contrasted what he perceived as having been a severe and callous lack of attention and care for or about BAME citizens on the part of the Labour Party in the past two decades, to his perception that Momentum recognises its own lack of racial and class diversity as a problem. He also drew an important connection between class, race and youth to suggest why so many of the staffers were both white and young. 
A white female paid staff member commented on diversity from the perspectives of gender and race:

I do see [diversity] happening but I do I think it could happen more. It could be more encouraging towards a different range of people. It's always difficult to get for example women involved because it's such already like historically it's been a male environment. And that's the same with politics. It's been like a male, a white male environment and it is always difficult to change that but Momentum probably could be doing more.

Roberta, 22

This staff member's response addressed a gender gap that existed in the national office staff, although there are many women in senior positions within Momentum. Like Munir and Jim's responses, Roberta's comments revealed a wider awareness within Momentum that their movement was not successfully addressing the issues of diversity and inclusion. The question that prompted the above response asked Roberta to comment on 'diversity' and did not define what was meant by the word; in her reply she spoke about diversity mainly in terms of gender diversity, albeit with an acknowledgment of the intersection with race in the phrase 'male, white environment'. This contrasts with the MLMS CEO's framing of diversity as about race, youth, and political persuasion, and suggests that the phrase 'diversity' means different things to different people within these youth citizenship organisations. This is one area in which we as researchers and participant observers with a shared interest in the social justice goals of the organisation had to be reflexive in acknowledging that, at the height of a political campaign, asking busy and over-worked informants to consider why and in what ways their 'diversity work' was falling short was not an ethical line of enquiry or an effective intervention.

\section{Campaign group communications}

When examining Momentum's voluminous online and social media public communications, as well as its official public documents, supporter emails, and other public materials, the contrast between its visual depictions of diversity and that of MLMS is notable. We analysed images from Momentum's Twitter activity from 1 April - 31 December 2017, which included the 2017 general election campaign, to get a sense of the types of people most likely to be visually featured on the timeline. The three individuals most likely to be depicted were Jeremy Corbyn, Theresa May, and the Guardian journalist Owen Jones (a vocal Momentum supporter and something of a mainstream media spokesperson through his columns and public speaking engagement). There was very little engagement of racial, gender or even youth diversity. There were, however, two explicit posts in late 2017 that directly addressed diversity (see below). Interestingly, during the same period, while MLMS' Twitter timeline featured far more people of colour in photographs, videos and 
advertisements, there were no explicit posts such as those from Momentum that directly addressed racial diversity as an issue MLMS worked on.

\title{
INSERT FIGURE 5.3 HERE TWO PICTURES SIDE-BY-SIDE
}

\author{
Banaji-Mejias Figure 5.3 LEFT SIDE IMAGE.png \\ Banaji-Mejias Figure 5.3 RIGHT SIDE IMAGE.png
}

Beyond these examples and a select few others (including two where Jeremy Corbyn was photographed with Black British celebrities including Stormzy), Momentum's online campaign practices did not include many appeals to diversity as a part of its campaigning or political communications. By virtue of its extremely close connections to the Labour party and to Labour leader Jeremy Corbyn, the audience for its communications seem to be the voting public who are either supporters of Labour, the Tories, Liberal Democrats or other miscellaneous parties on the Right and the Left - in other words, individuals targeted in terms of their potential to switch political affiliations. This is of course normal political campaign behaviour, but it does indicate that the notion of 'diversity' - that is, building a coalition of citizens committed to class, racial, gender, body, and sexual inclusivity, as an operating principle of politics - was not central to Momentum's communication strategy.

Both Momentum's public facing communications and our ethnographic observations and interviews make apparent a strong commitment to economic and social justice for all residents of the United Kingdom. The group fielded videos of supporters or local politicians who speak about needing political change in order for people to be able to afford to live decent and dignified lives in a time of austerity, or to build tolerance amongst communities and challenge xenophobic views. The themes of economic justice and social inequality reflected a progressive left view of politics, and also implicitly framed a political message of class diversity that could be attained via systemic changes promised by Corbyn and Labour. Momentum's politics clearly indicate a strong solidarity with an agenda to increase diversity, although it does not appear to occupy a significant pillar of its work.

\section{Conclusion}

Across MLMS and Momentum, conceptions of diversity were most similar when casting youth as the demographic group in need of greater inclusion in British politics. Yet each case presents an interesting example of how diversity becomes reified for young people engaging in civic or political projects.

MLMS embodies racial and ethnic diversity through their participant engagement practices (who shows up, how they get them there), personal (friends) and 
professional networks (e.g. the youth charity Bite the Ballot, who also focus on youth and minority equality in politics), cultural choices (what images are depicted on social media), and mission and values rhetoric. Diversity for MLMS also takes on neoliberal qualities through their use of the 'feel good' factor of getting young diverse citizens to debate politics (sometimes literally as a performance for the cameras, as witnessed at the Gina Miller event) to generate media attention and financial support from institutional political actors. MLMS appear to have a strong focus on marketing their cause in order to sustain and grow their work. Diversity is therefore simultaneously rhetorical (it is the discourse of their organisation), instrumental (it generates profit), and superficial (it masks structural issues). Momentum, on the other hand, embodies racial diversity primarily as it is constructed in the Labour party's political platform, as a pillar of an otherwise broader political movement for economic and social justice. They represent a very different case to MLMS, and while there were some clear examples of how diversity is a part of their work, it was rather peripheral to their overall activities.

Our study found that to a large extent MLMS' work aligns with Ahmed's (2007, 2009) argument about the way in which neoliberalism inflects - or infects - diversity discourses and practices. With the second case, Momentum's relative nonengagement with diversity as an aspect of their political campaigning activities does not offer any indication that, when framing or organising diversity work, they would employ market logic to 'sell' diversity as a part of their campaign group brand.

Overall, both groups express deep commitments to challenging inequalities and to the promise of progressive politics to enact structural change, and diversity work represents an aspect of that mission. Our findings suggest that there are areas where Momentum could further embrace and foreground diversity as part of a broader economic and social justice platform. Our study also suggests that, despite embodying diversity on a number of levels and offering real and meaningful opportunities for young people of colour to experience institutional politics, MLMS' diversity work could go even farther by focusing on the politics of structural change for racial as well as youth equality - for example, MLMS could explicitly champion structural change for increased diversity into their policy and event work, and be more explicit about how diversity drives their mission. But what is visible instead is the primacy of youth diversity to their mission; whereas Momentum campaigned around the Labour party manifesto, which included but did not focus explicitly on racial diversity. This engaging of only one type diversity only uses one plank of a powerful multi-plank equality platform.

Because both groups are political in nature there is little evidence of a depoliticisation of race in their conceptualisation and enactment of diversity - in fact the opposite is on view. It is clear that both groups recognised that race and diversity are fundamentally political issues, and that it is not possible to discuss diversity without discussing racism. Thus, our study suggests that in cases where politics underpins the work of youth citizenship groups or movements, as with MLMS and Momentum, 
there is potentially less risk of diversity becoming a 'technology for not hearing' (Ahmed, 2009, p. 47).

Importantly, both organisations' offline (collective) and online (connective) spaces for youth citizenship appeared to embody a kind of participatory 'filter bubble' (Pariser, 2011) by speaking within their narrowly defined, self-selecting audiences rather than across or reaching out to diverse groups of young people and political audiences. Our ethnography suggests that patterns of organisational diversity (e.g. with Momentum, its mostly white staff, and with MLMS, its BAME leadership and female staff) can operate as an offline 'filter bubble'. Furthermore, we argue that both offline and online networks reproduce the same narrow networks that do not match rhetoric of widening participatory diversity with concomitant practices (in the case of MLMS, even when 'diversity' becomes a rallying cry for the organisation's work). Our study cannot confirm previous findings of racial homophily in youth voluntary associations (Hampton \& Duncan, 2011) as it did not directly ask questions about racial identity formation in youth organisational settings. However our identification of potentially racialised participatory bubbles in each of our cases provides further indication that social capital in civic initiatives is racially inflected. Furthermore, it suggests that without an explicit focus on the substance of anti-racism, class and gender equality (irrespective of the fundamentally political nature of each group's engagement of diversity) racial and class homophily may be a potential de facto outcome, even for non-white groups such as those affiliated with MLMS, despite the fundamentally integrative nature of bringing people of colour into a mostly white institutional political space or set of spaces. It is therefore possible to infer, in line with the findings of Checkoway (2009), that in the cases of both MLMS and Momentum, explicit and direct education and action around racial, ethnic, gender, class, disability and other forms of marginalised or historically underrepresented identities might offer more substantive and transformative opportunities to promote equity and solidarity in a youth citizenship context.

\section{Notes}

${ }_{1}$ For example, see UpRising UK's mission to "break the cycle of unrepresentative power in the UK, by developing new, community-minded and socially-conscious leaders; so that our future decision-makers truly represent our diverse communities" (https://www.uprising.org.uk/about-us). Another example is the British Youth Council, which lists 'inclusive' as one of its core values and insist that "we ensure that all our activities our inclusive, recognising the needs of young people across different communities, and bring young people and partners together to learn from each other" (https://www.byc.org.uk/about-us/our-vision-mission-and-values).

${ }^{2}$ MLMS agreed to have its name made public for this study, but the CEO's name is withheld as all individual respondents are anonymised. 
${ }^{3}$ https://www.standard.co.uk/lifestyle/esmagazine/general-election-2017-whymillennials-votes-will-matter-a3539646.html. Retrieved 1 March 2019.

${ }^{4}$ https://www.telegraph.co.uk/news/politics/labour/12156177/momentum-activistsjeremy-corbyn-labour-purge.html. Retrieved 1 July 2019. 


\section{REFERENCES}

Ahmed, S. (2007). The language of diversity. Ethnic and Racial Studies, 30(2), 235256.

Ahmed, S. (2009). Embodying diversity: Problems and paradoxes for Black feminists. Race Ethnicity and Education, 12(1), 41-52.

Ahmed, S. (2012). On being included: Racism and diversity in institutional life: Duke University Press.

Ahmed, S. (2018). Sara Ahmed: On Complaint. YouTube video, 1:03:53. Retrieved from https://www.youtube.com/watch? $\mathrm{v}=4 \mathrm{j}$ BwPJoPTE.

Banaji, S., \& Buckingham, D. (2013). The civic web: young people, the Internet and civic participation. Cambridge, MA: MIT Press.

Banet-Weiser, S. (2012). Authentic TM: The Politics of Ambivalence in a Brand Culture. New York: New York University Press.

Banks, J. (2005). The Social Construction of Difference and the Quest for Educational Equality. In Z. Leonardo (Ed.), Critical Pedagogy and Race (pp. 93-110). Malden, MA: Blackwell Publishing.

Bennett, W. L., \& Segerberg, A. (2012). The Logic of Connective Action. Information, Communication \& Society, 15(5), 739-768.

Bonilla-Silva, E. (1997). Rethinking Racism: Toward a Structural Interpretation. American Sociological Review, 62(3), 465-480.

Bowl, M. (2018). Differentiation, distinction and equality - or diversity? The language of the marketised university: an England, New Zealand comparison. Studies in Higher Education, 43(4), 671-688.

Checkoway, B. (2009). Youth civic engagement for dialogue and diversity at the metropolitan level. The Foundation Review, 1(2), 5.

da Silva, D. F. (2007). Toward a Global Idea of Race.

Delgado, R., \& Stefancic, J. (1997). Critical white studies: Looking behind the mirror: Temple University Press.

Du Bois, W. E. B. (2007 [1903]). The Souls of Black Folk. Oxford: Oxford University Press.

Fanon, F. (1963). The Wretched of the Earth. New York: Grove Press.

Feagin, J. R. (2013). The white racial frame: Centuries of racial framing and counterframing: Routledge. 
Gurin, P. Y., Dey, E. L., Gurin, G., \& Hurtado, S. (2003). How does racial/ethnic diversity promote education? Western Journal of Black Studies, 27(1), 20.

Hall, S. (1997). The Spectacle of the 'Other'. In S. Hall (Ed.), Representation: Cultural Representation of Signifying Practices. London: Sage Publications.

Hampton, L. A., \& Duncan, E. M. (2011). Identities and inequalities: an examination of the role of racial identity in the formation of social capital inside a voluntary youth organization. Social Identities, 17(4), 477-500.

Kelly, E., \& Dobbin, F. (1998). How Affirmative Action became Diversity Management. American Behavioural Scientist, 47(7).

Leonardo, Z. (2002). The souls of white folk: Critical pedagogy, whiteness studies, and globalization discourse. Race Ethnicity and Education, 5(1), 29-50.

Levinson, M. L. (2010). The civic empowerment gap: Defining the problem and locating solutions. In L. Sherrod, J. Torney-Purta, \& C. Flanagan (Eds.), Handbook of Research on Civic Engagement (pp. 331-361). Hoboken, NJ: John Wiley \& Sons.

MacLeavy, J. (2008). Managing Diversity? 'Community Cohesion' and Its Limits in Neoliberal Urban Policy. Geography Compass, 2(2), 538-558.

Malik, S. (2013). "Creative Diversity": UK Public Service Broadcasting After Multiculturalism. Popular Communication, 11(3), 227-241.

Matus, C., \& Infante, M. (2011). Undoing diversity: knowledge and neoliberal discourses in colleges of education. Discourse: Studies in the Cultural Politics of Education, 32(3), 293-307.

Mejias, S., \& Banaji, S. (2017). UK Youth Perspectives and Priorities for Brexit Negotiations. Report for the All Party Parliamentary Group on a Better Brexit for Young People.

Mejias, S., \& Banaji, S. (2018). Backed into a corner: challenging media and policy representations of youth citizenship in the UK. Information, Communication \& Society, 22(12), 1714-1732.

Moyn, S. (2014). A powerless companion: Human rights in the age of neoliberalism. Law \& Contemporary Problems, 77, 147.

Pariser, E. (2011). The Filter Bubble: What the Internet is Hiding from You. New York: Penguin Press.

Said, E. W. (1995). Orientalism. Harmondsworth: Penguin.

Sanchez-Jankowski, M. (2002). Minority youth and civic engagement: The impact of group relations. Applied Developmental Science, 6(4), 237-245. 
Sloam, J., \& Henn, M. (2018). Youthquake 2017: the rise of young cosmopolitans in Britain: Springer.

Smith, N., Lister, R., Middleton, S., \& Cox, L. (2005). Young People as Real Citizens: Towards an Inclusionary Understanding of Citizenship. Journal of Youth Studies, 8(4), 425-443.

Spivak, G. C. (1988). Can the Subaltern Speak? In C. Nelson \& L. Grossberg (Eds.), Marxism and the Interpretation of Culture (pp. 271-313). Basingstoke: Macmillan Education.

Stewart, M., \& Lindburg, L. (1997). Gaining From Diversity. European Business Network for Social Cohesion, Brussels.

Wise, L. R., \& Tschirhart, M. (2000). Examining Empirical Evidence on Diversity Effects: How Useful is Diversity Research for Public Sector Managers? Public Administration Review, 60(5). 
